\title{
Bioedusiana
}

Blổogy

Education

\section{Penerapan Media Pembelajaran Komik Digital untuk Meningkatkan Hasil Belajar Siswa}

\section{Application of Digital Comic Learning Media to Improve Student Learning Outcomes}

\author{
Agi Septiari Narestuti ${ }^{1}$, Diah Sudiarti ${ }^{2 *}$, Umi Nurjanah $^{3}$ \\ 1,2,3 Program S1 Pendidikan Biologi, Fakultas Keguruan dan Ilmu Pendidikan, Universitas Islam Jember, \\ J1. Kyai Mojo No 101 Jember, Jawa Timur, Indonesia
}

\begin{abstract}
Abstrak
Keberhasilan pembelajaran abad 21 dapat diukur dengan antusiasme siswa dalam mengikuti kegiatan pembelajaran. Salah satu faktor yang mempengaruhi adalah kemampuan berpikir kreatif dan hasil belajar siswa dapat ditingkatkan dengan berbagai macam cara salah satunya dengan menggunakan media pembelajaran yang tepat saat proses pembelajaran yaitu media pembelajaran komik digital. Penelitian ini bertujuan untuk mengetahui peningkatan hasil belajar siswa kelas VIII pada materi sistem pernapasan di MTs Ma'arif Ambulu dengan menggunakan media pembelajaran komik digital. Metode penelitian yang digunakan adalah kualitatif dengan jenis penelitian yaitu penelitian tindakan kelas (PTK). Penelitian ini menggunakan dua siklus dan pada masing-masing siklus memiliki empat tahapan berupa 1) Perencanaan, 2) Pemberian Tindakan, 3) Observasi, dan 4) Refleksi. Sampel penelitian yang digunakan adalah siswa kelas VIII MTs Ma'arif Ambulu sebanyak 30 siswa. Berdasarkan penelitian menunjukkan media pembelajaran komik digital dapat meningkatkan hasil belajar siswa kelas VIII MTs Ma'arif Ambulu pada siklus I sebesar 61\% dengan kualifikasi cukup meningkat dan siklus II dengan persentase 93\% dengan kualifikasi meningkat. Hal tersebut membuktikan bahwa hasil belajar siswa meningkat setelah diterapkannya media pembelajaran komik digital.
\end{abstract}

Kata kunci: Media Pembelajaran; Komik Digital, Hasil Belajar

\begin{abstract}
The success of 21st-century learning can be measured by students' enthusiasm in participating in learning activities. One of the influencing factors is the ability to think creatively. Student learning outcomes can be improved in various ways, one of which is by using the right learning media during the learning process, namely comic digital learning media. This study aims to determine the improvement of class VIII student learning outcomes on respiratory system material at MTs Ma'arif Ambulu by using comic digital learning media. The research method used is qualitative with the type of research, namely classroom action research (CAR). This study uses two cycles, and each cycle has four stages, namely 1) Planning, 2) Giving Action, 3) Observation, and 4) Reflection. The research sample used was class VIII MTs Ma'arif Ambulu as many as 30 students. Research shows that digital comics learning media can improve the learning outcomes of class VIII MTs Ma'arif Ambulu students in the first cycle by $61 \%$ with high qualifications and the second cycle with a percentage of $93 \%$ with increased qualifications. This proves that student learning outcomes increase after the implementation of digital comic learning media.
\end{abstract}

Keywords: Learning Media; Digital Comic; Learning Outcomes.

\section{Article History}

Received: October 12 ${ }^{\text {nd }}, 2021$; Accepted: December 31 $1^{\text {st }}, 2021$; Published: December 31 $1^{\text {st }}, 2021$

Corresponding Author*

Diah Sudiarti, Pendidikan Biologi Universitas Islam Jember, E-mail: diah.sudiarti23@gmail.com

(C) 2021 Bioedusiana. This is an open access article under the CC BY-SA 4.0 license

(https://creativecommons.org/licenses/by-sa/4.0/)

\section{PENDAHULUAN}

Undang-Undang RI No. 20 Tahun 2003 tentang sistem pendidikan Nasional bab II Pasal 3 sebagai berikut: "Pendidikan bertujuan untuk mengembangkan potensi siswa agar menjadi manusia yang beriman dan bertaqwa kepada Tuhan Yang Maha Esa, berakhlak mulia, berilmu, kreatif, dan menjadi warga negara yang demokratis serta bertanggung jawab". 
Keberhasilan abad 21 dapat diukur dengan antusias siswa dalam mengikuti kegiatan pembelajaran. Salah satu faktor yang mempengaruhi adalah kegiatan pembelajaran di kelas, pembelajaran dikelas sangat berpengaruh dalam tercapainya prestasi belajar yang baik ( Nurrita, 2018).Untuk mencapai prestasi maka siswa juga harus aktif dalam mengikuti pembelajaran di kelas. Karena keberhasilan pembelajaran merupakan sumber dari segala aktivitas yang dilakukan guru dan siswa dalam proses pembelajaran, maka setiap guru harus berusaha mengoptimalkan berbagai faktor yang menjadi penghambat dalam proses pembelajaran dikelas. Keberhasilan proses pembelajaran yang mendukung pencapaian hasil belajar pada siswa dipengaruhi oleh banyak faktor misalnya guru, interaksi siswa, kurikulum, lingkungan sosial, dan media pembelajaran (Arum, 2017; Bustanil et al., 2019; Junaidi, 2019). Proses pembelajaran yang baik dapat tercapai apabila guru mampu mengarahkan siswa untuk mencapai tujuan pembelajaran dengan mengoptimalkan semua sumber daya yang ada baik di dalam maupun di luar kelas untuk mendukung ketercapaian tujuan pembelajaran.

Berdasarkan hasil observasi awal dengan guru pengampu mata pelajaran IPA di MTs Ma'arif Ambulu menunjukkan bahwa hasil belajar kognitif siswa rendah hanya mencapai 54\% dengan KKM 75. Hal ini dikarenakan masalah yang sering dihadapi siswa adalah penggunaan media pembelajaran yang kurang tepat dan belum banyak dikembangkan oleh guru di sekolah MTs Ma'arif Ambulu. Dampaknya, proses kegiatan belajar mengajar menjadi kurang menarik dan motivasi belajar peserta didik rata-rata masih rendah. Oleh karena itu, alternatif pemecahannya dibutuhkan komponen pembelajaran yang kreatif dan inovatif yang dapat memberikan kenyamanan pada siswa untuk memahami materi pelajaran IPA sehingga mampu dikuasai oleh siswa.

Dalam kegiatan proses pembelajaran di kelas perlu diciptakan kondisi kelas yang akrab dan menyenangkan bagi guru dan siswa. Kondisi tersebut dapat diciptakan dengan mengoptimalkan berbagai komponen pembelajaran, salah satunya media pembelajaran. Penggunaan media pembelajaran yang tepat mampu membantu peserta didik dalam memahami konsep yang sedang dipelajari, sehingga tidak lagi bersifat abstrak (Pitriana \& Jufri, 2015; Wulan et al., 2020). Oleh karena itu, peneliti bermaksud mencari solusi dari permasalahan berkaitan dengan media pembelajaran yang tepat, guna meningkatkan hasil belajar. Hasil belajar berupa perubahan sikap suatu individu setelah mendapatkan hasil dari kegiatan proses pembelajaran. Perubahan sikap tersebut berupa kemampuan baru seorang individu setelah melakukan proses pembelajaran yang meliputi beberapa ranah, yaitu kognitif yang meliputi pengetahuan dan pengembangan kemampuan intelektual siswa (Aimah, 2017).

Media pembelajaran digunakan untuk menyampaikan informasi dalam proses pembelajaran dikelas, serta dapat membangkitkan perhatian dan minat siswa dalam belajar ( Azhar, 2011). Untuk itu dalam suatu pembelajaran perlu direncanakan, evaluasi dan dimonitor 
atau pemantauan dengan sebaik-baiknya agar proses pembelajaran dapat memenuhi tujuan yang diinginkan. Dalam proses pengajaran, definisi media sering diartikan sebagai alat grafik, alat fotografi atau alat elektronik untuk menangkap, mengolah dan merekonstruksi informasi visual atau verbal.

Komik dapat digunakan untuk menyampaikan informasi dengan cara yang populer dan mudah dipahami. Komik menggabungkan kekuatan gambar dan kata-kata, dan menyusunnya menjadi suatu alur cerita agar informasi lebih mudah diserap. Teks membuatnya lebih mudah dipahami, dan alur cerita membuatnya lebih mudah untuk diingat dan di mengerti (Nasution, 2019), bahkan dalam jangka waktu yang lama (Wulan et al., 2020). Hal ini didukung oleh Kurniawati et al. (2018) yang menjelaskan bahwa science comic berpengaruh terhadap hasil belajar siswa kelas VIII pada materi sistem peredaran darah manusia di SMP Negeri 7 Jember. Komik digital besifat ramah lingkungan, hemat biaya, dan fleksibel. Disebut ramah lingkungan karena komik digital tidak menggunakan kertas sebagai media penyampaiannya sehingga menghemat penggunaan kertas. Komik digital dikategorikan hemat biaya karena tidak perlu dicetak, dijilid, dan disalin dalam bentuk buku (Hermawati, 2015). Komik digital merupakan media yang memudahkan siswa untuk memahami gambar secara keseluruhan, kemudian mengungkapkan idenya dengan baik, dan dapat menceritakan isi cerita secara runtut sehingga dapat digunakan pada proses pembelajaran. Dengan penggunaan media pembelajaran Komik Digital dapat menciptakan pembelajaran yang lebih aktif, kreatif, dan inovatif sehingga materi yang disampaikan dapat dengan mudah dipahami oleh peserta didik.

Keunggulan media komik digital antara lain: (1) Dilihat dari keunggulannya, komik dapat menarik semangat siswa untuk belajar dan mengajarkan siswa untuk mengolah cerita menjadi gambar sehingga dapat mengingat sesuatu dalam waktu yang lebih lama. (2) Materi yang terdapat pada komik dapat menjelaskan keseluruhan cerita, karena gambar ilustrasi dapat memudahkan siswa dalam memahami bentuk atau contoh spesifik mengenai tujuan materi. (3) Dapat Menumbuhkan minat baca siswa dan bidang studi lainnya. Kelemahan Media Komik Digital antara lain : (1) Tidak semua orang belajar secara efektif dalam gaya visual. (2) Terkadang gaya bahasa dalam komik kurang bagus. (3) Banyak komik berisi cerita yang menekankan kekerasan atau perilaku yang tidak dapat diterima (Kanti et al., 2018; Riwanto \& Wulandari, 2018).

Penggunaan media digital mampu membuat siswa menjadi kreatif, variatif, dan inovatif serta mampu membuat siswa merasa senang belajar IPA terutama materi biologi karena komik digital besifat ramah lingkungan, hemat biaya, dan fleksibel. Dikatakan ramah lingkungan karena komik digital tidak menggunakan kertas sebagai media penyampaiannya sehingga menghemat penggunaan kertas. Dengan adanya perpaduan ini maka diharapkan mampu menciptakan suasana belajar yang serius, namun tetap memiliki unsur gambar menarik yang menyenangkan siswa, sehingga siswa tidak merasa jenuh dan mengantuk di dalam proses pembelajaran. 


\section{METODE}

Pendekatan yang digunakan dalam penelitian ini adalah pendekatan kualitatif. Sedangkan jenis penelitian yang digunakan ini merupakan Penelitian Tindakan Kelas (PTK). Penelitian tindakan kelas (PTK) merupakan suatu penelitian yang dilakukan dalam kelas khususnya untuk meneliti permasalahan yang berkaitan dengan proses pembelajaran di kelas (Arikunto 2010). Penelitian tindakan kelas dilakukan secara bersiklus, yakni lebih dari satu siklus, dapat dilakukan dua atau tiga siklus atau bahkan lebih. Siklus yang dimaksud berupa putaran secara berulang dari kegiatan penelitian tindakan kelas yang terdiri dari perencanaan, pelaksanaan, observasi, dan refleksi. Adapun alur pelaksanaan tindakan yang dimaksud dapat dilihat dari tiap siklusnya dapat dilihat pada Gambar 1.

\section{Perencanaan}

Pada tahap ini menyiapkan instrumen perangkat pembelajaran, instrumen tes berupa posttest, dan membuat media pembelajaran yang diperlukan sesuai dengan indikator yang ingin dicapai.

\section{Pelaksanaan}

Pada tahap ini, peneliti melaksanakan kegiatan belajar mengajar menggunakan media komik digital pada materi sistem pernapasan. Selama proses berlangsung peneliti memberikan pelajaran kepada siswa dengan menggunakan perangkat pembelajaran berupa silabus, RPP, komik digital, dan posttest.

\section{Observasi}

Observasi dilakukan untuk mengetahui jalannya suatu proses pembelajaran secara menyeluruh dari kegiatan awal, inti, dan akhir.

\section{Refleksi}

Pada tahap ini yang dilakukan penelitian yaitu menganalisis hasil kerja siswa terhadap tes yang diberikan, menganalisis kekurangan dan hal-hal apa saja yang terjadi selama proses pembelajaran, kemudian mencari solusi agar kekurangan dan kendala yang ada tidak terulang kembali.

Perangkat pembelajaran yang digunakan dalam penelitian ini adalah RPP, lembar kerja siswa. Data penelitian berupa data ketuntasan hasil belajar peserta didik dikategorikan menjadi dua, yaitu secara individu maupun klasikal, dengan menganalisis data hasil tes menggunakan Kriteria Ketuntasan Minimal (KKM).

Waktu yang digunakan dalam penelitian ini dilaksanakan tanggal 17 Maret 2021, tempat pelaksanaan penelitian adalah MTs Ma'arif Ambulu. Populasi dalam penelitian ini adalah seluruh kelas VIII MTs Ma'arif Ambulu. Sampel dipilih dengan menggunakan purposive sampling, yaitu dengan mempertimbangkan kondisi sampel dari berbagai aspek, seperti distribusi hasil belajar 
peserta didik yang relatif homogen. Dengan demikian kelas yang terpilih sebagai sampel adalah kelas VIII B MTs Ma'arif Ambulu.

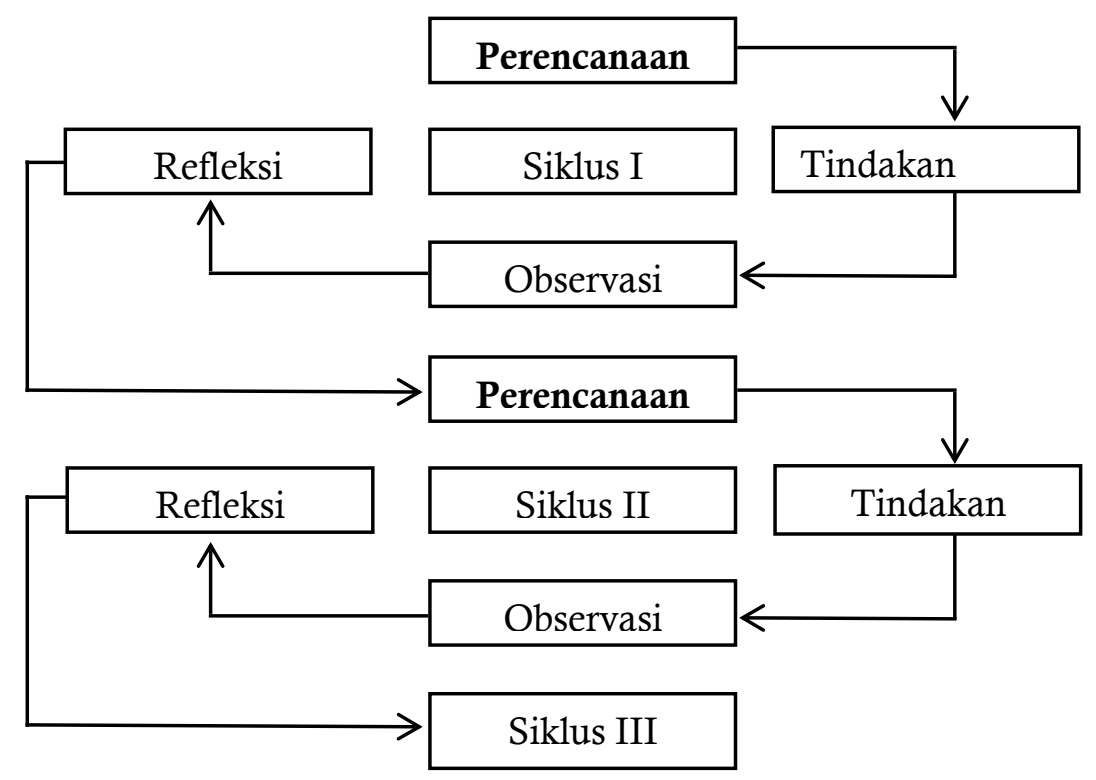

Gambar 1. Alur Pelaksanaan Penelitian Tindakan Kelas (Arikunto, 2010)

Variabel dalam penelitian ini terbagi menjadi dua, yaitu variabel terikat dan variabel bebas. Variabel terikat dalam penelitian ini adalah hasil belajar, sedangkan variabel bebas dalam penelitian ini adalah media pembelajaran komik digital.

Instrumen yang digunakan dalam penelitian ini adalah tes hasil belajar sebagai instrumen untuk mengukur hasil belajar siswa yang terbagi menjadi pre-test dan post-test. Tingkatan soal dibatasi pada ranah kognitif dari C1-C3 yang terdiri dari 10 soal pada materi sistem pernapasan, sebagai mana terdapat pada Tabel 1.

Tabel 1. Kisi-Kisi Instrumen yang akan Digunakan untuk Mengukur Hasil Belajar Pada Materi Sistem Pernapasan di MTs Ma'arif Ambulu

\begin{tabular}{|c|c|c|c|c|c|}
\hline \multirow[t]{2}{*}{ No } & \multirow[t]{2}{*}{ Materi } & \multicolumn{3}{|c|}{$\begin{array}{c}\text { Aspek Proses Kognitif yang } \\
\text { Diukur }\end{array}$} & \multirow[t]{2}{*}{ Jumlah } \\
\hline & & $\mathrm{C} 1$ & $\mathrm{C} 2$ & $\mathrm{C} 3$ & \\
\hline 1 & $\begin{array}{l}\text { Struktur dan fungsi organ pada sistem pernapasan } \\
\text { manusia }\end{array}$ & 1,3 & & 4 & 3 \\
\hline 2 & Mekanisme sistem pernapasan manusia & 8 & $2,5,6,7$ & & 5 \\
\hline 3 & $\begin{array}{l}\text { Kelainan atau penyakit pada sistem pernapasan } \\
\text { manusia }\end{array}$ & & 9 & & 1 \\
\hline 4 & Upaya menjaga sistem pernapasan manusia & & 10 & & 1 \\
\hline & Total & 3 & 6 & 1 & 10 \\
\hline
\end{tabular}

Kriteria Ketuntasan Minimal (KKM) yang digunakan adalah 75. Peserta didik dikategorikan tuntas apabila telah mencapai $\geq 75$, sedangkan peserta didik dikategorikan tuntas secara klasikal jika 75\% dari seluruh jumlah peserta didik di kelas tersebut mencapai KKM yang 
telah ditetapkan. Untuk mengetahui peningkatan hasil belajar siswa maka digunakan rumus berikut:

Keterangan:

$X \square:$ Nilai Rata-rata

$\Sigma X:$ Jumlah Semua Nilai

$$
X \square=\frac{\sum X}{\sum N}
$$

$\Sigma N$ : Jumlah Siswa yang Mengikuti Tes (Arikunto, 2010)

Sedangkan ketuntasan klasikal yaitu mengukur tingkat keberhasilan ketuntasan belajar siswa keseluruhan. Rumus ketuntasan belajar klasikal adalah sebagai berikut (Priyayi et al,. 2017):

$$
\text { Ketuntasan }=\frac{\text { jumlah siswa tuntas KKM }}{\text { jumlah total siswa }} \times 100
$$

\section{HASIL DAN PEMBAHASAN}

\section{Hasil}

Data hasil belajar pra-siklus diperoleh dari hasil pengukuran pengetahuan awal siswa sebelum dilakukan proses pembelajaran, melalui tes hasil belajar sebagaimana yang disajikan pada Tabel 2 berikut.

\begin{tabular}{|c|c|c|c|}
\hline No. & No. Induk Siswa & Nilai & Ketuntasan \\
\hline 1 & 190004 & 60 & Tidak Tuntas \\
\hline 2 & 190014 & 63 & Tidak Tuntas \\
\hline 3 & 190016 & 75 & Tuntas \\
\hline 4 & 190022 & 62 & Tidak Tuntas \\
\hline 5 & 190024 & 80 & Tuntas \\
\hline 6 & 190037 & 70 & Tidak Tuntas \\
\hline 7 & 190039 & 75 & Tuntas \\
\hline 8 & 190043 & 62 & Tidak Tuntas \\
\hline 9 & 190048 & 75 & Tuntas \\
\hline 10 & 190056 & 76 & Tuntas \\
\hline 11 & 190087 & 80 & Tuntas \\
\hline 12 & 190119 & 61 & Tidak Tuntas \\
\hline 13 & 190124 & 60 & Tidak Tuntas \\
\hline 14 & 190129 & 76 & Tuntas \\
\hline 15 & 190152 & 70 & Tidak Tuntas \\
\hline 16 & 190159 & 75 & Tuntas \\
\hline 17 & 190173 & 70 & Tidak Tuntas \\
\hline 18 & 190170 & 75 & Tuntas \\
\hline 19 & 190176 & 75 & Tuntas \\
\hline 20 & 190177 & 80 & Tuntas \\
\hline 21 & 190180 & 70 & Tidak Tuntas \\
\hline 22 & 190182 & 75 & Tuntas \\
\hline 23 & 190184 & 85 & Tuntas \\
\hline
\end{tabular}

Tabel 2. Data Hasil Belajar Siswa Pra Siklus 


\begin{tabular}{cccl}
\hline No. & No. Induk Siswa & Nilai & \multicolumn{1}{c}{ Ketuntasan } \\
\hline 24 & 190189 & 60 & Tidak Tuntas \\
25 & 190194 & 67 & Tidak Tuntas \\
26 & 190195 & 75 & Tuntas \\
27 & 190197 & 70 & Tidak Tuntas \\
28 & 190201 & 75 & Tuntas \\
\hline \multicolumn{4}{c}{ Nilai Rata-Rata } \\
Nilai Klasikal & 71,32 \\
\hline
\end{tabular}

Tabel tersebut menunjukkan data hasil belajar pra-siklus yang diukur dengan menggunakan pre-test. Berdasarkan data hasil belajar tersebut, diperoleh data masih banyak siswa yang masih belum tuntas, yaitu berada pada angka 13 orang siswa.

Setelah dilakukan pengukuran awal pada tingkat pengetahuan awal siswa, berikutnya adalah melaksanakan kegiatan pembelajaran pada siklus 1 dengan menggunakan media komik digital. Untuk mengetahui hasil dari pembelajaran siklus 1, maka dilakukan kembali pengukuran tingkat pengetahuan atau hasil belajar. Berikut ini data hasil belajar siklus 1 sebagaimana disajikan pada Tabel 3 berikut.

Table 3. Data Hasil Belajar Siswa Siklus I

\begin{tabular}{|c|c|c|c|}
\hline No. & No. Induk Siswa & Nilai & Ketuntasan \\
\hline 1 & 190004 & 75 & Tuntas \\
\hline 2 & 190014 & 59 & Tidak Tuntas \\
\hline 3 & 190016 & 80 & Tuntas \\
\hline 4 & 190022 & 62 & Tidak Tuntas \\
\hline 5 & 190024 & 95 & Tuntas \\
\hline 6 & 190037 & 74 & Tidak Tuntas \\
\hline 7 & 190039 & 90 & Tuntas \\
\hline 8 & 190043 & 62 & Tidak Tuntas \\
\hline 9 & 190048 & 61 & Tidak Tuntas \\
\hline 10 & 190056 & 76 & Tuntas \\
\hline 11 & 190087 & 90 & Tuntas \\
\hline 12 & 190119 & 61 & Tidak Tuntas \\
\hline 13 & 190124 & 61 & Tidak Tuntas \\
\hline 14 & 190129 & 76 & Tuntas \\
\hline 15 & 190152 & 70 & Tidak Tuntas \\
\hline 16 & 190159 & 80 & Tuntas \\
\hline 17 & 190173 & 75 & Tuntas \\
\hline 18 & 190170 & 75 & Tuntas \\
\hline 19 & 190176 & 75 & Tuntas \\
\hline 20 & 190177 & 80 & Tuntas \\
\hline 21 & 190180 & 75 & Tuntas \\
\hline 22 & 190182 & 75 & Tuntas \\
\hline
\end{tabular}




\begin{tabular}{clcl}
\hline No. & No. Induk Siswa & Nilai & Ketuntasan \\
\hline 23 & 190184 & 73 & Tidak Tuntas \\
24 & 190189 & 80 & Tuntas \\
25 & 190194 & 67 & Tidak Tuntas \\
26 & 190195 & 75 & Tuntas \\
27 & 190197 & 60 & Tidak Tuntas \\
28 & 190201 & 75 & Tuntas \\
\hline \multicolumn{4}{r}{ Nilai Rata-rata } \\
\hline
\end{tabular}

Tabel 3 menunjukkan data hasil belajar pada siklus I, dari data hasil belajar yang diperoleh menunjukkan masih terdapat siswa yang belum tuntas, yaitu dengan jumlah 11 siswa. Berdasarkan hasil post test pada Tabel 3, rata-rata hasil belajar siswa mencapai 70,79, dan secara klasikal hasil belajar siswa mencapai nilai $61 \%$. Adapun skor yang diperoleh juga menunjukkan hasil bahwa terdapat beberapa siswa yang tidak mencapai nilai 75 (KKM) yaitu sebanyak 11 siswa yang tidak tuntas, sedangkan 17 siswa lainnya dinyatakan tuntas dalam pembelajaran dan 2 orang tidak mengikuti pembelajaran dikarenakan berhalangan hadir.

Kemudian, sebelum dilakukan proses pembelajaran ke siklus berikutnya, terlebih dahulu dilakukan evaluasi untuk mengetahui faktor yang harus diperbaiki di pembelajaran sebelumnya. Selanjutnya, guru dan siswa masuk ke proses pembelajaran siklus II, dan diperoleh hasil belajar siswa sebagaimana yang disajikan pada Tabel 4 berikut.

Tabel 4. Data Hasil Belajar Siswa Siklus II

\begin{tabular}{clcl}
\hline No. & Nomor Induk Siswa & Nilai & Ketuntasan \\
\hline 1 & 190004 & 80 & Tuntas \\
2 & 190014 & 95 & Tuntas \\
3 & 190016 & 69 & Tidak Tuntas \\
4 & 190022 & 80 & Tuntas \\
5 & 190024 & 100 & Tuntas \\
6 & 190037 & 98 & Tuntas \\
7 & 190039 & 94 & Tuntas \\
8 & 190043 & 100 & Tuntas \\
9 & 190048 & 93 & Tuntas \\
10 & 190056 & 98 & Tuntas \\
11 & 190087 & 89 & Tuntas \\
12 & 190119 & 70 & Tidak Tuntas \\
13 & 190124 & 80 & Tuntas \\
14 & 190129 & 85 & Tuntas \\
15 & 190152 & 90 & Tuntas \\
16 & 190159 & 73 & Tidak Tuntas \\
17 & 190173 & 85 & Tuntas \\
18 & 190170 & 80 & Tuntas
\end{tabular}




\begin{tabular}{clcl}
\hline No. & Nomor Induk Siswa & Nilai & Ketuntasan \\
\hline 19 & 190176 & 85 & Tuntas \\
20 & 190177 & 90 & Tuntas \\
21 & 190180 & 90 & Tuntas \\
22 & 190182 & 80 & Tuntas \\
23 & 190184 & 100 & Tuntas \\
24 & 190189 & 80 & Tuntas \\
25 & 190194 & 90 & Tuntas \\
26 & 190195 & 89 & Tuntas \\
27 & 190197 & 78 & Tuntas \\
28 & 190201 & 80 & Tuntas \\
\hline \multicolumn{5}{c}{ Rata-rata } \\
\hline \multicolumn{2}{c}{ Nilai Klasikal } \\
\hline
\end{tabular}

Data hasil belajar siswa pada Tabel 4 tersebut menunjukkan bahwa jumlah siswa sebanyak 30 siswa dan 2 siswa tidak mengikuti pembelajaran dikarenakan berhalangan hadir. Pada Tabel 4 tersebut menunjukkan peningkatan hasil belajar dari siklus sebelumnya, hal ini dapat dilihat bahwa hasil belajar rata-rata siswa kelas VIII B pada siklus II mencapai 83,60, sedangkan ketuntasan secara klasikal adalah 93\% dengan banyaknya siswa yang tuntas sebanyak 25 siswa, siswa yang tidak tuntas sebanyak 3 dan 2 tidak hadir dalam pembelajaran.

\section{Pembahasan}

Pelaksanaan pada penelitian ini dapat disebut berjalan dengan baik dan terdapat peningkatan hasil belajar siswa dengan diterapkannya media pembelajaran komik digital dari siklus pembelajaran I ke siklus pembelajaran II. Hal ini dapat dilihat pada grafik Gambar 1 berikut ini.

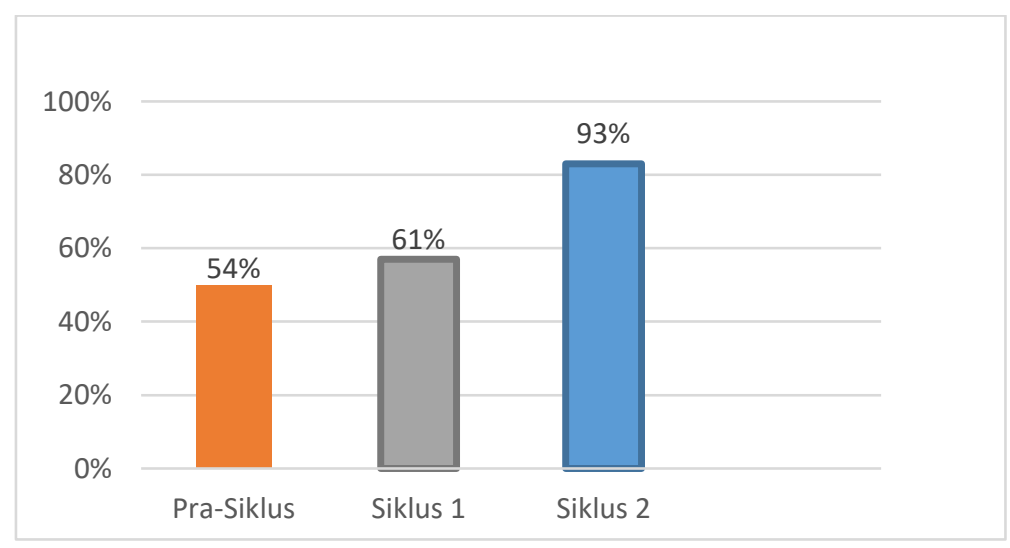

Gambar 2. Peningkatan hasil belajar siswa pada setiap siklus pembelajaran

Sebelum diterapkannya media pembelajaran komik digital dikelas VIII B MTs Ma'arif Ambulu persentase hasil belajar siswa hanya mencapai 54\%, dimana hanya terdapat kurang lebih 15 siswa yang mencapai nilai KKM. Pada siklus I siswa yang tuntas sebanyak 17 siswa tuntas atau 
sudah mencapai nilai $\mathrm{KKM} \geq 75$ dari skor maksimal 100, dan pada siklus II siswa yang tuntas sebanyak 26 siswa tuntas atau sudah mencapai nilai $K K M \geq 75$ dari skor maksimal 100. Nilai kognitif hasil belajar siswa-siswi pada siklus I yaitu 70,79 dan pada siklus II yaitu 83,60. Jika dilihat dari ketuntasan secara klasikal pada siklus I nilai klasikal mencapai $61 \%$ dan pada siklus II mencapai 93\%, maka dari data diatas tersebut hasil belajar siswa sudah meningkat dengan diterapkannya media pembelajaran komik digital, dan data ini sudah mencapai pada indikator keberhasilan yakni apabila adanya peningkatan hasil belajar siswa dalam setiap pembelajaran dari siklus I sampai siklus II mencapai nilai $\geq 75 \%$.

Dalam proses pembelajaran menggunakan media komik digital dapat dikategorikan menarik, hal ini dapat dilihat dari antusiasme siswa selama kegiatan pembelajaran berlangsung dikarenakan siswa diberikan gambar-gambar yang menarik dalam komik sehingga sangat disukai siswa, kegiatan membaca buku bergambar atau komik merupakan kegiatan menghibur dan menyenangkan dengan gambar-gambar yang atraktif, berwarna, dan format sampul yang menarik (Gambar 3), sehingga dilihat dari penampilannya saja siswa sudah tertarik untuk melihat dan membaca buku tersebut (Muflikhatur, 2015).
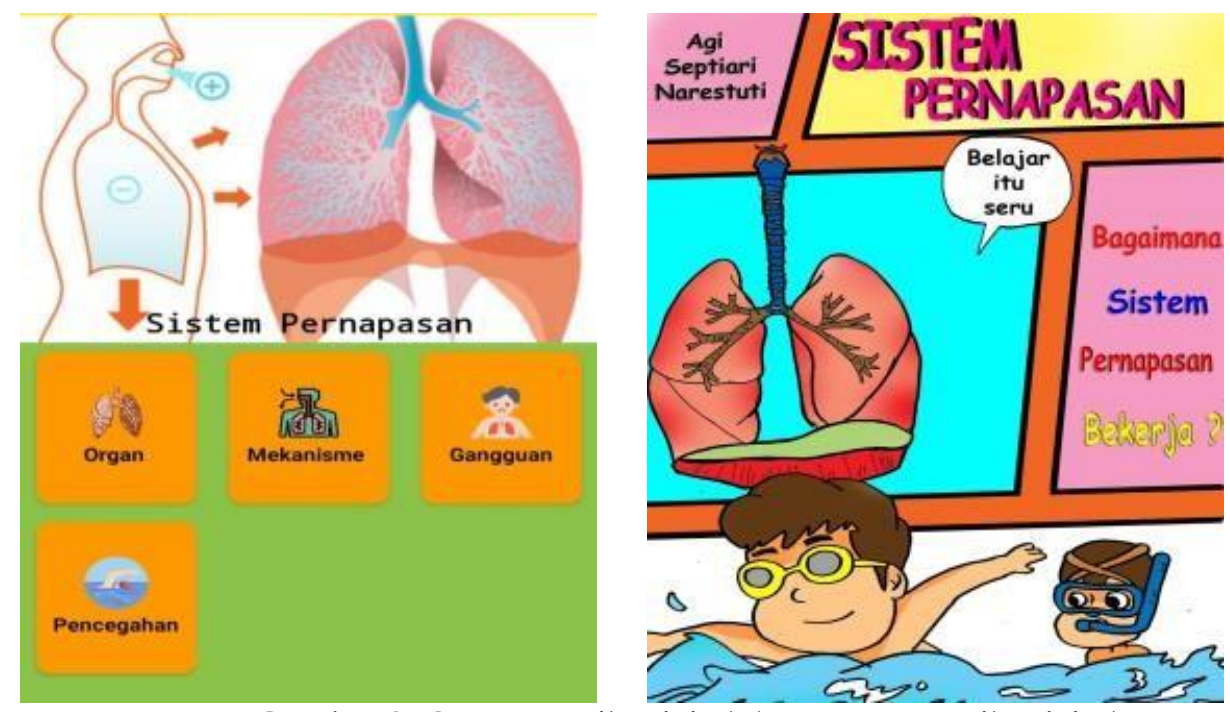

Gambar 3. Cover Komik Digital dan Menu Komik Digital

Isi dari komik digital meliputi cover, judul, kata pengantar daftar isi, pengenalan tokoh, dan materi. Pada desain tampilan cover yang merupakan tampilan pertama dari komik menggunakan desain yang simpel dengan bantuan warna biru, coklat dan merah muda ditambah dengan gambar. Dapat dilihat gambar diatas merupakan menu komik digital yang terdiri dari: (1) Organ yang di dalamnya membahas mengenai hidung, tekak (faring), pangkal tenggorokan, batang tenggorok, dan paru-paru. (2) Mekanisme yang di dalamnya membahas mengenai proses bagaimana udara masuk ke dalam tubuh, pernapasan perut dan pernapasan dada, alat-alat pernapasan, pertukaran oksigen dan karbondioksida dalam paru-paru, dan cepat lambatnya 
pernapasan. (3) Gangguan yang di dalamnya membahas mengenai kenapa kita bersin, menghirup udara yang berpolusi, penyebab kita menguap, bagaimana bisa mendengkur, cegukan, dan asma atau sesak napas. (4) Pencegahan yang di dalamnya membahas mengenai jauhilah rokok, waspada terhadap Mycobacterium tuberculosis, dan cara menjaga kesehatan.

Dari penelitian yang telah dilakukan di MTs Ma'arif Ambulu dapat dilakukan Penerapan media pembelajaran komik digital ini efektif untuk membantu keberhasilan proses pembelajaran. Hasil data yang diperoleh, yakni adanya peningkatan pada pembelajaran sebelum diterapkannya media pembelajaran komik digital, yaitu persentase belajar siswa hanya mencapai $54 \%$ dan sesudah adanya penerapan media pembelajaran komik digital dikelas VIII B MTs Ma'arif Ambulu Persentase menjadi meningkat pada siklus I yaitu $61 \%$ dan pada siklus II menjadi $93 \%$. Hal ini karena memiliki kelebihan pada media pembelajaran komik digital seperti penelitian yang dilakukan oleh Noning (2018) bahwa pembelajaran dengan media komik berpengaruh terhadap hasil belajar siswa pada sub materi Pencemaran Lingkungan dikelas VII SMP Air Besar.

Kelebihan dari media pembelajaran ini diantaranya adalah: (1) Dapat membantu siswa untuk mudah memahami isi materi yang akan dipelajari. (2) Siswa dapat memahami materi yang dipelajari, karena media pembelajaran komik digital dapat menumbuhkan minat baca siswa. (3) Media pembelajaran komik digital dapat mendorong siswa untuk memiliki sikap bekerja sama, jujur, disiplin, dan belajar memahami suatu konsep masalah. Hal ini sejalan dengan pernyataan Kustianingsari \& Dewi (2015) bahwa materi yang terdapat di dalam komik dapat menjelaskan keseluruhan cerita karena terdapat ilustrasi gambar yang dapat mempermudah siswa mengetahui bentuk atau contoh kongkrit mengenai maksud dari suatu materi.

Kelemahan dari media komik digital diantaranya adalah: (1) Membutuhkan alokasi waktu yang cukup panjang untuk melakukan pembelajaran. (2) Menuntut sifat tertentu pada siswa, salah satunya suka membaca. (3) Kemudahan membaca komik menyebabkan penolakan-penolakan atas buku-buku yang tidak bergambar.

Tetapi kekurangan tersebut berhasil diatasi, sehingga penggunaan media pembelajaran ini dapat meningkatkan hasil belajar karena siswa dapat lebih mudah mengingat dan memahami materi yang dipelajari. Hal ini sejalan dengan Nurrita (2018), bahwa media visual dapat mempermudah siswa untuk memahami konsep dari materi yang sedang diajarkan serta mengingat kembali materi yang disampaikan oleh guru. Berdasarkan data-data dari siklus I dan siklus II, terjadi peningkatan hasil belajar siswa sebelum dan sesudah perlakuan penerapan media pembelajaran komik digital pada materi sistem pernapasan dikelas VIII MTs Ma'arif Ambulu dengan kata lain media pembelajaran komik digital dapat meningkatkan hasil belajar dan dapat digunakan sebagai alternatif dalam pembelajaran seperti pada penelitian yang dilakukan oleh Nugraheni, (2017), Barokahhuda et al., (2021), dan Wulan et al., (2020) dimana penggunaan 
media pembelajaran komik digital dalam proses pembelajaran mempermudah siswa untuk memahami materi dan membantu siswa dalam mengikuti proses pembelajaran.

Media pembelajaran komik digital mampu membuat siswa menjadi kreatif, variatif, dan inovatif serta mampu membuat siswa merasa senang belajar IPA terutama materi biologi. Dengan adanya komik ini maka diharapkan mampu menciptakan suasana belajar yang serius, namun tetap menyenangkan siswa, sehingga siswa tidak merasa jenuh dan mengantuk di dalam proses pembelajaran.

\section{SIMPULAN}

Berdasarkan Data hasil penelitian di kelas VIII B MTs Ma'arif Ambulu diperoleh kesimpulan yaitu pembelajaran menggunakan media pembelajaran komik digital dapat meningkatkan hasil belajar siswa. Hal ini dapat dilihat dari hasil belajar yang didapat oleh siswa pada pra siklus hanya mencapai $54 \%$, kemudian pada siklus I diperoleh hasil belajar secara klasikal sebanyak $61 \%$ dengan rata-rata sebanyak 70,79. Sedangkan pada siklus II mencapai nilai $93 \%$ dengan rata-rata sebanyak 83,60. Ini menunjukkan bahwa media pembelajaran komik digital efektif untuk diterapkan dalam pembelajaran karena mampu meningkatkan hasil belajar siswa.

\section{REFERENSI}

Aimah, M. (2017). Penggunaan Aplikasi Macromedia Flash Sebagai Media Pembelajaran Interaktif Untuk Meningkatkan Hasil Belajar Siswa. Bioshell Vol.6 No.01 2017

Arikunto, S. (2002). Prosedur Penelitian (Suatu Pendekatan Praktek). Jakarta: PT. Rineka Cipta. Arum, W. F. (2017). Pengaruh Model Pembelajaran Double Loop Problem Solving dan Problem Posing pada Materi Fluida. Jurnal Teknika STTKD, 4(2), 40-50.

Azhar, A. (2011). Media Pembelajaran, Jakarta: PT Raja Grafindo Persada.

Barokahhuda, U., Sumarmin, R., \& Yogica, R. (2021). Analisis Kebutuhan untuk Pengembangan Bahan Ajar Berbentuk Komik Manga pada Materi Jaringan Hewan Kelas XI SMA. Bioedusiana: Jurnal Pendidikan Biologi, 6(1), 88-103. https://doi.org/https://doi.org/10.37058/bioed.v6i1.2968

Bustanil, S., M., Asrowi, \& Adianto, D., T. (2019). Pengembangan Media Pembelajaran Interaktif Berbasis Video Tutorial Di Sekolah Menengah Kejuruan. JTP - Jurnal Teknologi Pendidikan, 21(2), 119-134. https://doi.org/10.21009/jtp.v21i2.11568

Hermawati, T. (2015). Komik digital untuk pembelajaran yang menyenangkan. http://guraru.org/guru-berbagi/komik-digital-untuk-pembelajaran-yang-menyenangkan Diakses pada tanggal 3 januari 2021

Junaidi, J. (2019). Peran Media Pembelajaran Dalam Proses Belajar Mengajar. Diklat Review : Jurnal Manajemen Pendidikan Dan Pelatihan, 3(1), 45-56. https://doi.org/10.35446/diklatreview.v3i1.349

Kanti, F. Y., Suyadi, B., Hartanto, W. (2018). Pengembangan Media Pembelajaran Komik Digital pada Kompetensi Dasar Sistem Pembayaran dan Alat Pembayaran untuk Siswa Kelas XI IPS di MAN 1 Jember. Jurnal Pendidikan Ekonomi: Jurnal Ilmiah Ilmu Pendidikan, Ilmu Ekonomi, dan Ilmu Sosial, 12(1). 135-141. https://doi.org/10.19184/jpe.v12i1.7642 
Kurniawati, D., Ismul, M. A. H., Sukamto, D. S. (2018). Pengaruh Science Comic Terhadap Hasil Belajar Siswa. BIOEDUSAINS: Jurnal Pendidikan Biologi dan Sains, 1(2). 106-114. https://doi.org/10.31539/bioedusains.v1i2.455

Kustianingsih, N., Dewi, U. (2015). Pengembangan Media Komik Digital pada Mata Pelajaran Bahasa Indonesia Tema Lingkungan Sahabat Kita Materi Teks Cerita Manusia dan Lingkungan untuk Siswa Kelas V SDN Putat Jaya III/379 Surabaya. Jurnal Mahasiswa Teknologi Pendidikan, 6(2). 1-9.

Lestari S. (2009). Media Grafis; Media Komik. Bandung : Jurusan Kurikulum dan Teknologi Pendidikan Universitas Pendidikan Indonesia. (Online).(Http://File.Upi.Edu/Direktori/Fip/Jur._Kurikulum_Dan_Tek._Pendidikan/19 7706132001122laksmi_Dewi/Media_Grafis/Media_Grafishs1_Mhsisswa/Komik/Medgra $\mathrm{f}, \mathrm{Pdf})$

Muflikhatur R., Wan, S. (2015). The Development Of Comic As Media Learning For Scince 8th Grade Junior School At Subject Transportation System, hlm.7-8. Jurnal Ilmu Pendidikan Biologi

Nasution, A. E. (2019). E-Kompen (Elektronik-Komik Pendek) sebagai solusi cerdas dalam meningkatkan minat baca masyarakat Indonesia di era digital. IQRA`: Jurnal Ilmu $\begin{array}{lllll}\text { Perpustakaan Dan Informasi } & \text { (e-Journal), }\end{array}$ https://doi.org/10.30829/iqra.v13i1.4365

Noning. (2018). Efektivitas Komik Terhadap Hasil Belajar Siswa Materi Pencemaran Lingkungan SMP Negeri 1 Air Besar. JPPK: Jurnal Pendidikan dan Pembelajaran Khatulistiwa, 7(1).

Nugraheni, N. (2017). Penerapan Media Komik Pada Pembelajaran Matematika Di Sekolah Dasar. Refleksi Edukatika: Jurnal Ilmiah Kependidikan, 7(2), 111-117. https://doi.org/10.24176/re.v7i2.1587

Nurrita, T. (2018). Pengembangan Media Pembelajaran Untuk Meningkatkan Hasil Belajar Siswa. Misykat, 3(1). 171-187.

Priyayi, D. F., Nurani, D. E., Hastuti, S. P. (2017). Peningkatan Hasil Belajar Kognitif Pada Pembelajaran Biologi Siswa Kelas Xi Ipa 2 Sma Negeri 1 Pabelan Melalui Penerapan Seminar Nasional Pendidikan Sains II UKSW 2017 Seminar Nasional Pendidikan Sains II UKSW 2017. 179-186.

Pitriana, D., \& Jufri. (2015). The Use of Cartoon Movie as a Media in Teaching Vocabulary to Young Learners. Journal of English Language Teaching, 1(2), 106-113.

Riwanto, M. A., Wulandari, M. P. (2018). Efektivitas Penggunaan Media Komik Digital (Cartoon Story Maker) dalam Pembelajaran Tema Selalu Berhemat Energi. Jurnal Pancar, 2(1). 14-18

Saputra, R. (2019). Pengaruh Tahapan Share Dan Reflect Pada Metode Pembelajaran Creative Learning Cycle Terhadap Pencapaian Keahlian Abad Ke- 21. Journal of Chemical Information and Modeling, 53(9), 1689-1699.

Wulan, I. S., Suprapto, P. K., \& Kamil, P. M. (2020). Belajar Virus dengan Komik: Pengaruhnya terhadap Motivasi dan Hasil Belajar (Studi Eksperimen di Kelas X MAN Tasikmalaya Tahun Ajaran 2019/2020). Bioedusiana: Jurnal Pendidikan Biologi, 5(2), 70-83. https://doi.org/10.37058/bioed.v5i2.2005 